\title{
BOVINE COAGULASE-NEGATIVE STAPHYLOCOCCI: BIOCHEMISTRY AND POLYMERASE CHAIN REACTION
}

\author{
R. HUMMEL and G. LEHMANN \\ Veterinär- und Lebensmittelinstitut, 07743 Jena, Federal Republic of Germany
}

Received September 22, 1994

\begin{abstract}
Hu m me l, R., G. Leh m a n : Bovine coagulase-negative Staphylococci: Biochemistry and Polymerase Chain Reaction. Acta vet. Brno, 63, 1994: 133-139.

Staphylococcus (S.) simulans, S. chromogenes, and S. epidermidis were the species of coagulase-negative staphylococci (CNS) most frequently involved in subclinical mastitits of dairy cattle. The same biochemical features characterized the successive isolates of a particular chronically infected udder quarter. Occurrence rate of the various species differed between the herds examined. In cases of clinical mastitis of cows $S$. xylosus, $S$. simulans, $S$. haemolyticus, and $S$. chromogenes predominated. A comparison between strains of the particular CNS species from infections in man and cattle did not show host attributable biochemical features or profiles obtained by polymerase chain reaction using arbitrary primers (AP-PCR).
\end{abstract}

Bovine mastitis, Coagulase-negative staphylococci, biochemical features, polymerase chain reaction

Coagulase-negative staphylococci (CNS) can by frequently isolated from milk samples of dairy cows, often in association with subclinical mastitis ( $\mathrm{T}$ i m m s et al. 1987; Ha rm on and L a n glo is 1989; W at t s et al. 1989; David son et al. 1992; Mat the ws et al. 1992; Todhunter et al. 1993). For differentiation between species of CNS several approaches have been supposed. Typing schemes primarily based on panels of biochemical tests have often been applied in tandem with other methods including composition of cell wall, isoenzyme pattern, polymorphism of whole cell protein and penicillin binding protein, pattern of rRNA gene and of endonuclease cleaved DNA, polymerase chain reaction using arbitrary primers (AP-PCR). By AP-PCR Welsh and Mc Clelland (1990) obtained species specific patterns of AP-PCR products. Moreover, Staphylococcus (S.) haemolyticus of human and non-human primate origin produced different AP-PCR patterns related to their ecological origin and supposedly to host specifity of strains. The purpose of this work is to study (1) involvement of the various CNS species in udder infections of cows and (2) comparison between strains within the particular CNS species originating from man and cattle by means of AP-PCR.

\section{Materials and Methods}

\section{Bacterial strains}

The CNS examined in this study originated from cases of clinical mastitis (54 strains) and of subclinical mastitits ( 57 strains) in cattle. For comparison, 8 strains from infections in man were included in these studies.

Of the strains from bovine clinical mastitis 41 were isolated from udder secretions in 39 dairy herds submitted for bacteriological examination to the regional veterinary laboratory. An additional 13 strains originated from Belgium.

The 57 strains from subclinical mastitis were selected in five large herds of cattle (Table 1) with 300 to 500 cows each. An infection of the mammary gland means isolation of CNS in pure culture together with an elevated total cell count ( $>300000$ cells $/ \mathrm{ml}$ milk). Sampling of udder secretions was carried out before and after milking. Repeated isolates from a particular udder quarter possessed of the same biochemical features were considered a single strain. The 57 strains represented a total of 580 isolates. All of the herds practised post milking teat dipping but only two of them (herds $\mathrm{Np}$ and $\mathrm{Lu}$ ) applied a proper hygiene at milking. There was an occasional history of Streptococcus agalactiae in these herds and the infected cows were removed for slaughter.

In herd Np quarter milk samples from 463 cows at freshening were investigated for the presence of CNS infections. 21 cows with 29 chronically CNS infected quarters in herd Np were resampled monthly or bimonthly to the next freshening. The 29 strains represented a total of 502 isolates. In herds $\mathrm{Mo}$ and $\mathrm{Zi}$, respectively, 7 out of 197 and 3 out of 293 cows could be found chronically infected. Three consecutive samplings were performed and a total of 42 isolates gathered. Herds $\mathrm{Ka}$ and $\mathrm{Lu}$ have been sampled only once. 
Table 1

CNS infections in herds of cattle

\begin{tabular}{|c|c|c|c|c|c|c|}
\hline & $\begin{array}{l}\text { herd of cattle } \\
\mathrm{Np}\end{array}$ & Mo & $\mathbf{Z i}$ & $\mathbf{K a}$ & Lu & MST \\
\hline $\begin{array}{l}\text { cows/quarters } \\
\text { examined }\end{array}$ & $463 / 1846$ & $197 / 774$ & $293 / 1150$ & $207 / 822$ & $97 / 394$ & \\
\hline $\begin{array}{l}\text { cows/quarters } \\
\text { CNS infected }\end{array}$ & $\begin{array}{c}43 / 59 \\
(9 \% / 4 \%)\end{array}$ & $\begin{array}{c}21 / 21 \\
(4 \% / 1 \%)\end{array}$ & $\begin{array}{c}20 / 26 \\
(11 \% / 4 \%)\end{array}$ & $\begin{array}{c}25 / 29 \\
(7 \% / 1 \%)\end{array}$ & $\begin{array}{c}3 / 3 \\
(3 \% /<1 \%)\end{array}$ & \\
\hline $\begin{array}{l}\text { cow/quarters } \\
\text { chronically infected }\end{array}$ & $21 / 29$ & $7 \pi 7$ & $3 / 4$ & ne & ne & \\
\hline $\begin{array}{l}S C^{x} \text { in quarters } \\
\text { free of CNS } \\
\text { with CNS }\end{array}$ & $\begin{array}{l}4 \times 10^{4} \\
5 \times 10^{5}\end{array}$ & $\begin{array}{l}5 \times 10^{4} \\
6 \times 10^{5}\end{array}$ & $\begin{array}{l}1 \times 10^{5} \\
8 \times 10^{5}\end{array}$ & $\begin{array}{l}8 \times 10^{4} \\
6 \times 10^{5}\end{array}$ & $\begin{array}{l}2 \times 10^{4} \\
4 \times 10^{5}\end{array}$ & \\
\hline $\begin{array}{l}\text { strains identified } \\
\text { to species level } \\
\text { S. simulans } \\
\text { S. chromogens } \\
\text { S. epidermidis } \\
\text { S. xylosus } \\
\text { S. warneri } \\
\text { S. haemolyticus } \\
\text { S. cohnii } \\
\text { S. saprophyticus } \\
\text { total number }\end{array}$ & $\begin{array}{c}17 \\
9 \\
2 \\
1\end{array}$ & $\begin{array}{l}2 \\
1 \\
4\end{array}$ & $\begin{array}{l}2 \\
1 \\
1\end{array}$ & $\begin{array}{l}3 \\
9 \\
1 \\
1\end{array}$ & $\begin{array}{l}1 \\
2\end{array}$ & $\begin{array}{c}9 \\
6 \\
2 \\
11 \\
3 \\
8 \\
1 \\
1 \\
41\end{array}$ \\
\hline
\end{tabular}

Explanatory notes:

MST, strains from cases of clinical mastitis from 39 herds of cattle; $x$, somatic cell count from quarter milk samples of CNS infected cows only; $y$, chronically infected quarters; $z$, quarters sampled but once; ne, not examined.

\section{Sampling procedures}

Prior to sampling, the udder of each cow was washed, dried, and desinfected thoroughly, and about $15 \mathrm{ml}$ of foremilk from each quarter were discarded. Than the two individual quarter samples, one before, one after automatic milking, were collected in separate test tubes. Samples were kept on ice until starting the laboratory examination within the next 6 to 15 hours.

Microbiology and somatic cell count

Each milk sample $(0,1 \mathrm{ml})$ was streaked onto the quadrant of a $3 \%$ blood agar plate. Plates were incubated for 48 hours at $37^{\circ} \mathrm{C}$. A single colony of each primary culture of abundant growth (at least 10 colonies) yielding pure cultures with only one morphologically homogenous type of CNS was selected for further studies. Somatic cell counts (SCC) were done using a Fossomatic cell counter (A/SN, Hillerod, Denmark).

Biochemical characterization of CNS

Methods described by Kl oos et al. (1974) were applied for biochemical characterization of strains. In addition, sensitivity to furazolidone was tested according to $\mathrm{R} \mathrm{h}$ e in $\mathrm{h}$ a b e $\mathrm{n}$ and $\mathrm{Hadlock}$ (1981); sensitivity to novobiocin according to Devrie se (1979). Production of phosphatase, urease, hyaluronidase, heat stable DNase and splitting of Tween 80 was studied as described by Devrie se et al. (1883). Production of glucosidase and glucoronidase was determined according to $\mathrm{W}$ hi te et al. (1990). Inhibition of delta-hemolysin was detected as described by S kalka (1991). Strains were identified to genus level on the basis of culture and cell morphology, pigmentation, Gram stain, catalase activity, hemolysis, clumping factor, coagulase of rabbit and human plasmas and sensitivity to furazolidone. The identification to species level was based on features contained in table 2. Production of heat stable DNase, hyaluronidase, splitting of Tween 80 and inhibition of delta-hemolysin were only determined for differentiation between $S$. hyicus and $S$. chromogenes. From the reaction patterns thus obtained CNS species were determined by using the data base of Geary et al. (1989) modified at the Institute for Experimental Epidemiology, Wernigerode.

For control, the following strains were used: S. epidermidis (CCM 2124), S. hominis (CCM 2732), S. haemolyticus (CCM 2737), S. warneri (CCM 2730), S. saprophyticus (CCM 883), S. simulans (CCM 2705), S. xylosus (CCM 2738), S. sciuri (CCM 3433), S. cohnii (CCM 2736), S. hyicus (CCM 2368), S. chromogenes (CCM 3387), Micrococcus luteus (CCM 169).

\section{AP-PCR}

A total of 50 strains of bovine and 8 of human origin were examined. Table 3 shows the origin of the strains. Genomic DNA of the strains was isolated by the method of B i a lk ow ska-Hobrzan sk a et al. (1990). AP-PCR procedure was carried out according to Willi a ms et al. (1990) using the following three 10mer primers already applied by Willi a m s et al. (1990): namely

5'TCACGATGCA (designated primer 1), 5'ACGGTACACT (primer 2), 5'CACATGCTTC (primer 3). The primers have been synthesized by Dr. Birch-Hirschfeld, Institute for Molecular Biotechnology, Jena. Concentration of the primers used was $4 \mu \mathrm{M}$ and $0,2 \mu \mathrm{M}$ for both primers 1 and 2 , while $1 \mu \mathrm{M}$ was applied for primer 3 . Two runs 
of PCR experiments in duplicate tubes were carried out with each of the template DNA. The reagent control that should not produce any amplification product contained all components used for AP-PCR but without addition of template DNA. Amplification products were analyzed by electrophoresis in 1,4\% agarose gel and detected by staining with ethidium bromid. Size markers were the $1 \mathrm{~kb}$ DNA ladder from GIBCO BRL.

\section{Results}

Mastitis and CNS species

The occurrence of subclinical mastitis associated with CNS in 1257 cows in the five herds of cattle, mean values of somatic cell count (SSC), and CNS species involved are presented in Table 1. On the basis of biochemical features six CNS species were identified among the 57 strains recovered from the five dairy herds. The same biochemical features characterized the successive isolates of a particular quarter, and the successive isolates were considered a single strain. Occurence and prevalence of the various species differed between the five herds of cattle, but, $S$. simulans, S. chromogenes, and S. epidermidis predominated in chronical infections. Among the 41 CNS strains from 39 farms isolated from quarters with clinical mastitis, the four species S. xylosus, S. simulans, S. haemolyticus, and S. chromogenes were found in relatively high frequency (Table 1$)$, while another four species $(S$. warneri, $S$. epidermidis, S. saprophyticus, and S. cohnii) were infrequent.

\section{Characteristics of the CNS strains}

The features of the CNS strains investigated by biochemical methods are shown in Table 2 . All of the strains could be identified to species level with high certainty except for some of the $S$. chromogenes strains. 9 out of the $26 \mathrm{~S}$. chromogenes strains were classified being S. chromogenes despite their ability to split Tween 80 and their lack in pigment production.

The various patterns of biochemical reactions within the particular CNS species were detected among the strains originating from the same herd of cattle, from different dairy herds as well as among the strains from diseases in man.

\section{AP-PCR}

The AP-PCR experiments performed with 58 strains representing four different CNS species resulted in reproducible patterns of amplified DNA.

Origin and species of the strains tested, the patterns of amplified DNA, and the number of different AP-PCR profiles observed within each of the species are listed in Table 3. Here, an AP-PCR profile includes all patterns of amplified DNA generated with a given strain by each of the three primers at the various concentrations applied.

For the species S. chromogenes, S. epidermidis, S. simulans and S. xylosus two, three, five, and six AP-PCR profiles, respectively, were observed. There was no correlation between the groups of AP-PCR profiles within a CNS species and the origin of strains neither from cattle of different dairy herds nor from man or cattle.

Between one and five amplificates resulted from each fingerprinting. The size of the amplificates increased in most of the cases as the concentration of a primer in the AP-PCR reaction decreased. Each primer at each of the concentrations used gave different patterns of DNA amplificates with a potential of detecting polymorphisms between species and between groups of strains. Some of these patterns observed within a particular species, however, were rather similar or even the same.

\section{Discussion}

The results of the study indicating the infrequent occurrence of CNS associated subclinical mastitis in dairy cows are in agreement with reports from the literature (Ti m m s and Schultz 1987; Harmon and Langlois 1989; Rainard etal. 1990; Davids on et al. 
Table 2

Pattern of blochemical reactions in CNS species

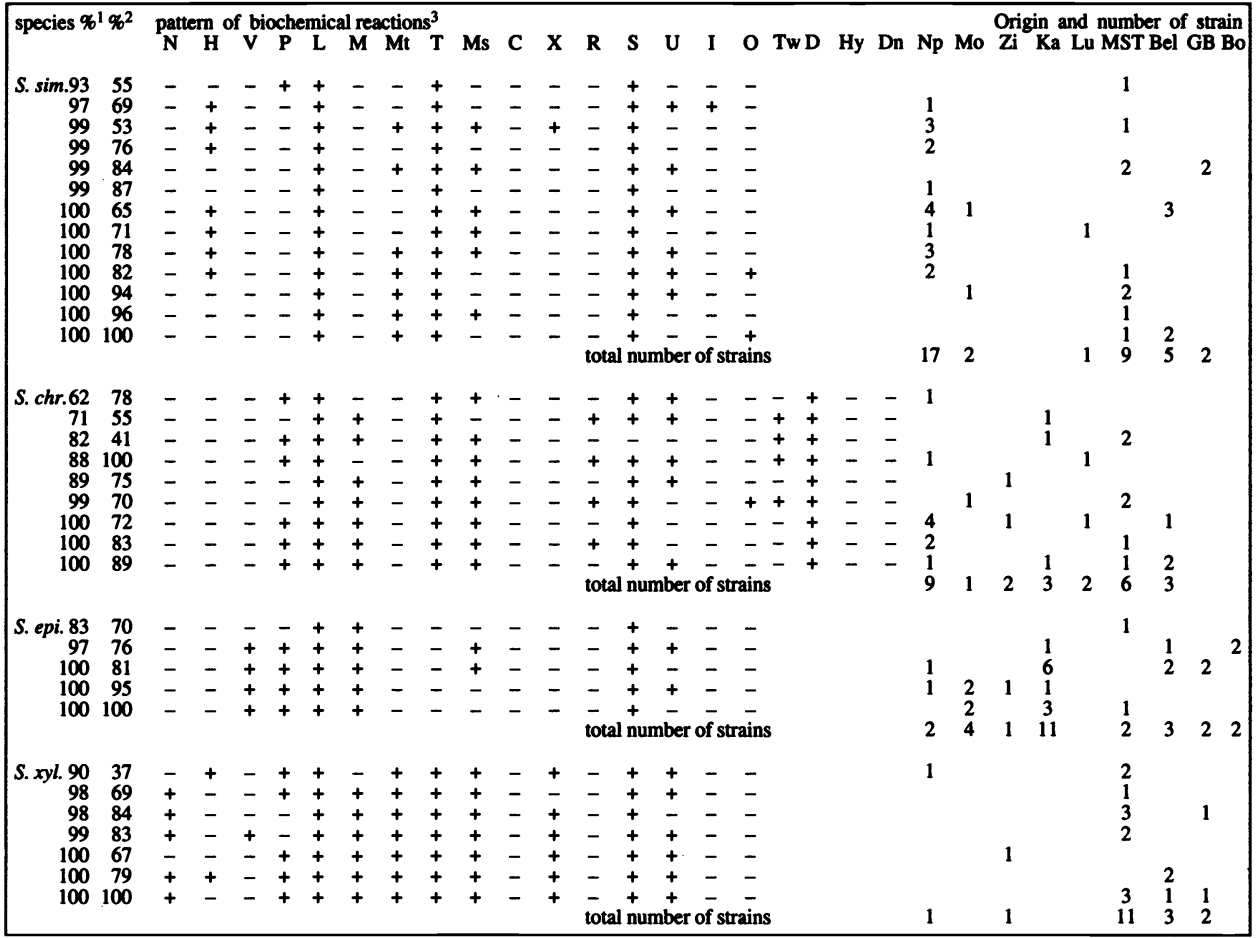

1 percent probability of diagnosis; 2 percent security of probability; $\mathrm{N}$ sensitivity to novobiocin; $\mathrm{h}$ hemolysis; $\mathrm{V}$ acetoin; $\mathrm{P}$ phosphatase; $\mathrm{L}$ lactose; $M$ maltose; Mt mannitol; T trehalose; Ms mannose; $C$ cellobiose; $X$ xylose; $R$ ribose; $U$ urease; I glucosidase; Tw Tween 80; D inhibition of delta hemolysin; Hy hyaluronidase; DN DNase; dairy herds Np, Mo, ZI, KA, Lu; MST clinical mastitis, Bel Belgium; GB Great Britain; Bo Bonn

1992). A prevalence of $S$. chromogenes and $S$. simulans in subclinical mastitis (W at ts et al. 1984; Harmon and Langlois 1989; Jarp 1991; Mat the ws et al. 1991; 1992; Todhunter et al. 1993; own data in table 1) suggest a rather good adaption of these two species to the bovine udder, although occurrence rate of the various CNS species can differ between dairy herds. On contrary, occurrence of the species $S$. xylosus, S. epidermidis, S. haemolyticus, and S. saprophyticus in quarters with clinical mastitis, sometimes with higher frequency than $S$. chromogenes and S. simulans (B a b a et al. 1980; B r o w n 1983; M a t the w s et al 1992; own data in table 1) may demonstrate the potential of an environmental strain to enter the bovine udder. Their occurrence may primarily be related to an inflammation of the mammary gland and one should suppose that, exept for S. xylosus, they have directly originated from the milkers. S. xylosus has been isolated from used straw and from fresh unused straw (White et al. 1989), it was also detected being the predominant species of CNS on the skin of domestic animals ( $\mathrm{S} \mathrm{h} \mathrm{i} \mathrm{mi} \mathrm{zu}$ et al. 1992) and occurred in large numbers on the teat skin of cows (Devriese and De Ke y ser 1980). This environmental CNS species rarely occurring in chronically infected udders should be considered a transient rather than a resident microflora.

In identification the CNS strains studied by biochemical methods we met no difficulties except for 9 strains assigned to $S$. chromogenes. They take a somewhat intermediate position between $S$. chromogenes and $S$. hyicus, a finding already ruled out by $S \mathrm{k}$ al k a (1991). Two of the crucial features discriminating both species were atypical for $S$. chromogenes: the strains produced pigment weakly or not at all and splitted Tween 80 . 
Table 3

Patterns and sizes (kilobases) of AP-PCR amplificates for CNS strains from man and cattle

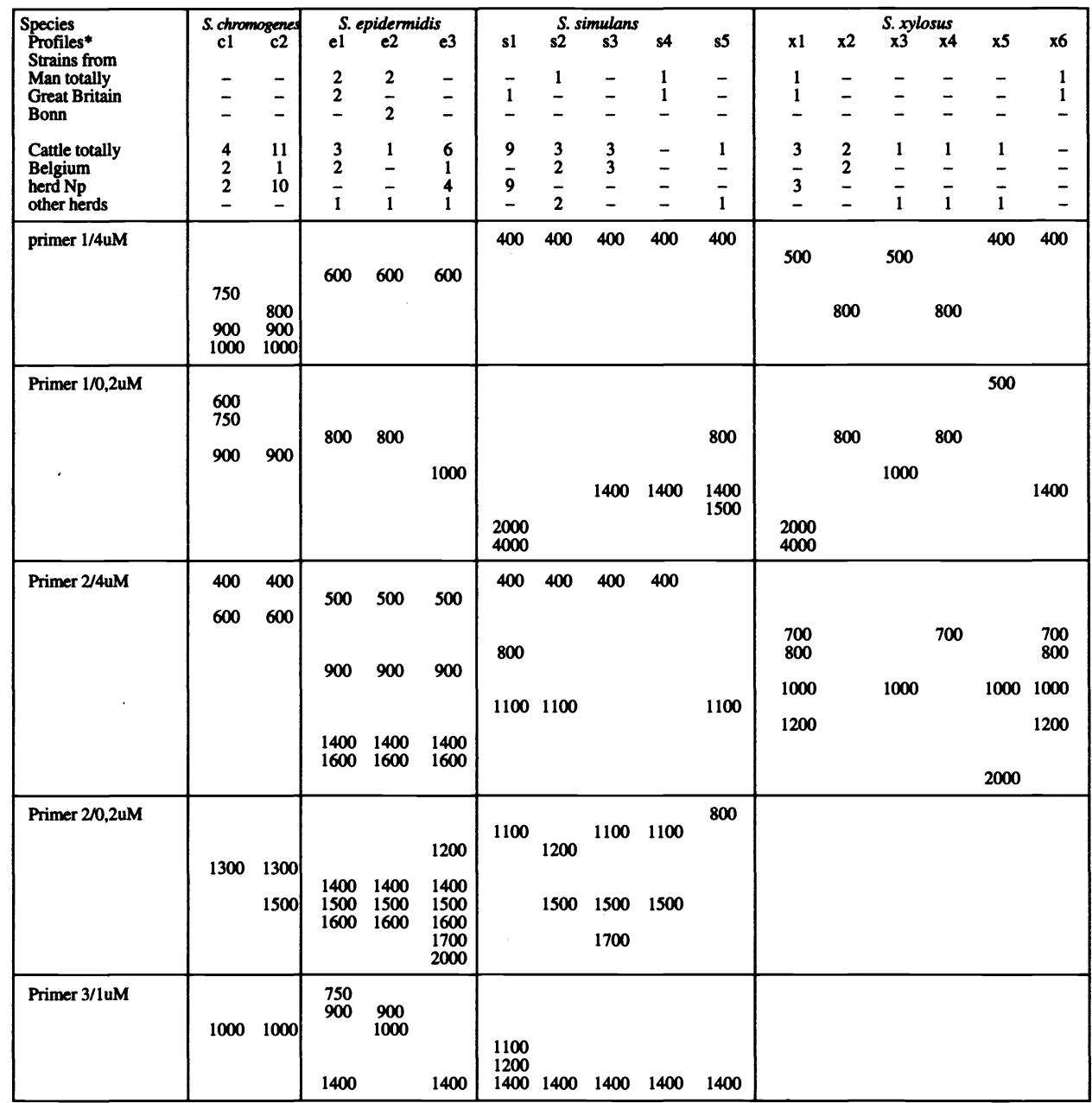

The AP-PCR studies with our strains revealed only weakly pronounced species specific profiles, while Welsh and McClelland (1990) clearly distinguished CNS species by AP-PCR although a few of their AP-PCR products were shared between species. Host attributable amplificate profiles within the CNS species studied could not be detected with our strains indicating a close relationship between the strains from man and cattle. Especially, the amplificate patterns and profiles were quite similar within the species $S$. epidermidis. Findings yielded by ribotyping seem to provide a comparable view. De B u y ser et al. (1992) obtained a number of equal hybridization patterns with strains of different host origin belonging to a same CNS species by ribotyping using ribosomal RNA gene probes and restriction endonuclease cleaved DNA. For example, equal hybridization patterns were observed for $S$. xylosus strains isolated from man, goat, and horse, or for S. epidermidis, S. warneri, and $S$. lugdunensis strains from man and goat. On the contrary, in strains from human and nonhuman primates, We l s ch and McClell and (1990) observed different AP-PCR pat- 
terns indicating the existence of host adapted subspecies. For CNS of human and non other primate origin Kloos and Wolf shohl $(1979 ; 1983)$ confirmed the hypothesis of a conjugate evolution of microorganisms with their host by DNA hybridization. The question rises whether the conditions in animal husbandry favour a mutual exchange of CNS strains between man and animals, thus being the reason for a close relationship between them. To answer this question, DNA homology studies with human and bovine strains of the particular CNS species are needed that can provide the most exacting data to determine the taxonomic status and relatedness of the species and the existence of subspecies.

\section{Bovinní koaguláza-negativní stafylokoky: biochemie a polymerázová řetězová reakce}

Druhy Staphylococcus (S.) simulans, S. chromogenes, a S. epidermidis jsou druhy koaguláza-negativních stafylokokủ (CNS), nejčastěji se vyskytujících při subklinických mastitidách dojnic. Izoláty $\mathrm{z}$ chronicky infikovaných čtvrtí mléčné žlázy byly charakterizovány stejnými biochemickými vlastnostmi. Frekvence výskytu různých druhů se u vyšetřovaných stád lišila. V prípadech klinických mastitid dojnic převládaly $S$. xylosus, $S$. simulans, a S. chromogenes. Srovnáním kmenů CNS humánní a bovinní provenience nebyly nalezeny odlišné biochemické vlastnosti ani profily získané pomocí polymerázové řetězové reakce.

\section{Коагуляза-негативная крупного рогатого скота стафилококками: биохимия и цөпная реакция полимеризации}

Виды Staphylococcus (S.) simulans, S. chromogenes и S. epidermidis являются видами коагуляза-негативных стафилококков (CNS), чаще всего встречающиеся в время субклинических маститов дойных коров. Изоляты хронически инфицированных четвертей молочной железы отличались одинаковыми биохимическими свойствами. Частота наличия разных видов у отдельных исследуемых стад отличалась. В случае клинического мастита дойных коров преобладающими явились $S$. xylosus, S. simulans и S. chromogenes. Сопоставлением CNS человека и крупного рогатого скота не выявили отличающихся биохимических свойств ни профилей, полученных с помощью цепной реакции полимеризации.

\section{Acknowledgements}

We thank Dr. Francoise Schumacher-Perdreau, Bonn Federal Republic of Germany, Dr. L. A. Devriese, Gent, Belgium, and Dr. R. R. Marples, London, England, for providing staphylococcal strains. We also thank Dr. E. BirchHirschfeld, Institute of Molecular Biotechnology, Jena Federal Republic of Germany for synthesis of primers. The technical assistance of Annett Held and Birgit Lemser is greatly appreciated.

\section{References}

BABA, E. - FUKUTA, T. - MATSUMOTO, H.: Ecological studies on coagulase-negative staphylococci in and around the bovine udder. Bul. Univ. Osaka Prev., Ser B 32, 1980: 69-75.

BIALKOWSKA-HOBRZANSKA, H. - JASKOT, D. - HAMMERBERG, O.: A method for DNA restriction endonuclease fingerprinting of coagulase-negative staphylococci. J. Microbiol. Meth., 12, 1990: 41-49

BROWN, R. W.: Biotypes of Staphylococcus epidermidis and Micrococcus organisms, isolated from intramammary infections, reclassified into species of the genus Staphylococcus (epidermidis, hyicus, xylosus, and sciuri). Cornell Vet., 73, 1983: 109-116

DAVIDSON, T. J. - DOHOO, J. R. - DONALD, A. W. - HARIHARAN, H. - COLLINS, K.: A cohort study of coagulase negative staphylococcal $\mathbf{M}$ in selected dairy herds in Prince Edward Island. Can. J. Vet. Res., 56, 1992: $275-280$. 
DE BUYSER, M. L. - MORVAN, A. - AUBERT, S. - DILASSER, F. - EL SOLH, N.: Evaluation of a ribosomal RNA gene probe for the identification of species and subspecies within the genus Staphylococcus. J. Gen. Microbiol., 138, 1992: 889-899

DEVRIESE, L. A.: Identification of clumping-factor-negative staphylococci isolated from cow's udders. Res. Vet., Sci., 27, 1979: 313-320

DEVRIESE, 1. A. - DeKEYSER, H.: Prevalence of different species of coagulase-negative staphylococci in teats and in milk samples from dairy cows. J. Dairy Res., 47, 1980: 155-158

DEVRIESE, L. A. - VLAMINCK, K. - NUYTTEN, J. - DeKEERSMAEKER, PH.: Staphylococcus hyicus in skin lesions of horses. Equine Vet. J., 15, 1983: 263-265

GEARY, C. - STEVENS, M. - SNEATH, P.H.A. - MITCHELL, C. J.: Construction of a database to identify Staphylococcus species. J. Clin. Path., 42, 1989: 289-294

HARMON, R. J. - LANGLOIS, B. E.: Mastitis due to coagulase-negative Staphylococcus species. Agri-Practice, 10, 1989: 29-31

JARP, J.: Classification of coagulase-negative staphylococci isolated from bovine clinical and subclinical mastitis. Vet. Microbiol., 27, 1991: 151-158

KLOOS, W. E. - TORNABE, G. - SCHLEIFER, K. H.: Isolation and characterization of micrococci of human skin, including two new species: Micrococcus lilae and Micrococcus kristinae. Int. J. Syst. Bact, 24, 1974: 79-101

KLOOS, W. E. - WOLFSHOHL, J. F.: Evidence for deoxyribonucleotide sequence divergence between staphylococci living on human and other primate skin. Curr. Microbiol., 3, 1979: 167-172

KLOOS, W. E. - WOLFSHOHL, J. F.: Deoxyribonucleotide sequence divergence between Staphylococcus cohnii subspecies populations living on primate skin. Curr. Microbiol., 8, 1983: 115-121

MATTHEWS, K. R. - HARMON, R. J. - LANGLOIS, B. E.: Effect of naturally occurring coagulase-negative staphylococci infections on new infections by mastitis pathogens in the bovine. J. Dairy Sci., 74, 1991: 1855-1859

MATTHEWS, K. R. - HARMON, R. J. - LANGLOIS, B. E.: Prevalence of Staphylococcus species during periparturient period in primiparous and multiparous cows. J. Dairy Sci., 75, 1992: 1835-1839

RAINARD, P. - DUCELLIEZ, M. - POUTREL, B.: The contribution of mammary infections by coagulase-negative staphylococci to the herd bulk milk somatic cell count. Vet. Res. Comm., 14, 1990: 193-198

RHEINHABEN, K. E. - HADLOCK, R. M.: Rapid distinction between micrococci and staphylococci with furazolidone agars. Antonie van Leeuwenhoek, 47, 1981: 41-51

SKALKA, B.: Diagnostic value of the characteristics of Staphylococcus hyicus and Staphylococcus chromogenes. Acta Vet. Brno, 60, 1991: 277-283

SHIMIZU, A. - OZAKI, J. - KAWANO, J. - SAITOH, Y. - KIMURA, S.: Distribution of Staphylococcus species on animal skin. J. Vet. Med. Sci., 54, 1992: 355-357

TIMMS, L. L. - SCHULTZ, L. H.: Dynamics and significance of coagulase-negative staphylococci intramammary infections. J. Dairy Sci., 79, 1987: 2648-2653

TODHUNTER, D. A. - CANTWELL, L. L. - SMITH, K. L. - HOBLET, K. H. - HOGAN, J. S.: Characteristics of coagulase-negative staphylococci isolated from bovine intramammary infections. Vet. Microbiol., 34, 1993: 373-380

WATTS, J. L. - OWENS, W E.: Prevalence of staphylococcal species in four dairy herds. Res. Vet. Sci., 46, 1989: 1-5

WELSH, J. - McCLELLAND, M.: Fingerprinting genomes using PCR with arbitrary primers. Nucl. Acids Res., 18., 1990: 7213-7218

WHITE, D. G. - HARMON, R. J. - MATOS, J. E. S. - LANGLOIS, B. E.: Isolation and identification of coagulase-negative Staphylococcus species from bovine body sites and streak canals of nulliparous heifers. J. Dairy Sci., 72, 1990: 1886-1892

WHITE, D. G. - HARMON, R. J. - LANGLOIS, B. E.: Fluorogenic assay for differentiating Staphylococcus warneri and Staphylococcus hominis strains of bovine origin. J. Clin. Microbiol., 28., 1990: 602

WILLIAMS, J. G. K. - KUBELIK, A. R. - LIVAK, K. J. - RAFALSKI, J. A. - TINGEY, S. V.: DNA polymorphisms amplified by arbitrary primers are useful as genetic markers. Nucl. Acids Res., 18, 1990: 6531-6535

This study was supported by grant of the Deutsche Forschungsgemeinschaft. 